\title{
Greece as a frontline state in the historical longue durée
}

DOI 10.2478/jms-2021-0010

Received: December 09, 2020; Accepted: June 12, 2021

\begin{abstract}
Greece as a state in South-eastern Europe and the Mediterranean has perceived itself as a frontline state, especially after it became a NATO member in 1952 along with Turkey. The two states formed the south-eastern flank of NATO and along with Iran constituted the Greece, Turkey, Iran (GTI) Corridor, part of Rimland. Greece's strategic value stemmed from its frontline position in relation to the Eastern Bloc. After the dissolution of the Eastern Bloc, Greece has reinvented itself as a frontline state, this time in the Mediterranean Sea. We use the historical notion of longue duree and loci of Classical Geopolitics, such as Heartland and Rimland, to assess Greece's strategic value in the long period. We also propose an additional spatial unity, the New Rimland.
\end{abstract}

Keywords: NATO, GTI Corridor, Heartland, Rimland, frontline state, New Rimland

\section{Methodology and introductory remarks}

Our interpretation of the strategic orientation of Greece adopts a macro-historical point of view and is connected to specific thematic loci of Classical Geopolitics and an underlying typology of historical time proposed by the French Annales School of historical writing. The French Annales School distinguishes between three levels of historical time. The first level, defined as short-time, is related to specific events that are manifested in a limited period, as revolutions, wars or other political and military conflicts. The second level, middle-time, is related to social transformation and small-scale demographic changes. The third level, the long-time or long-term (longue durée), emphasises the hermeneutic importance of geophysical

\footnotetext{
*Corresponding author: Ioannis Kotoulas, Adjunct Lecturer in Geopolitics, Faculty of Turkish and Modern Asian Studies, University of Athens, Athens, Greece;

E-mail: ikotoulas@turkmas.uoa.gr
}

and macro-historical structures, such as geography, including geographical position and formation and the cultural references of a population (Braudel 1958). In this context of historical approach, Classical Geopolitics offers a useful set of terms.

Classical Geopolitics, a hermeneutic model used in our analysis, was formulated in the early 20th century according to specific spatial entities and thematic loci found in the work of the main proponents of the AngloSaxon Geopolitical School, i.e. Alfred Thayer Mahan (1840-1914), Sir Halford John Mackinder (1861-1947) and Nicholas J. Spykman (1893-1943) (Mahan 1890; Mackinder 1904; Mackinder 1919; Spykman 2007 [1942]; Spykman 1944). Classical Geopolitics resorts to loci, such as the distinction between sea powers and land powers and geopolitical spatial unities of Heartland and Rimland in Eurasia.

According to Classical Geopolitics, state actors are distinguished between sea powers, i.e. states able to project power in the seas, and land powers, i.e. states whose manifestation of power is located on continental areas. The US and Great Britain belong typically to sea powers, while USSR/Russia and Germany are categorised as land powers. The geopolitical dimension of a state and its respective typological categorisation depend on its relation to a specific geographical area or another state. France, for example, is both a land and sea power; it is one of the continental European powers when it is compared to solely maritime Great Britain, but functions as a sea power in relation to the states in the Eastern Mediterranean, as its power is projected by its aeronautical abilities.

Heartland is a spatial unity that evolved out of the initial concept of Pivot Area devised by the founder of Anglo-Saxon Geopolitical School, Sir Halford John Mackinder (1861-1947) (Mackinder 1904; Mackinder 1919). Heartland comprises the inaccessible area of Eastern Europe and Siberian inland that before the advent of air power could not be reached by the maritime forces of the Western sea powers. Mackinder later expanded the area of Heartland to include also the semi-closed peripheral seas adjacent to the main core, i.e. the Baltic Sea and the Black Sea. Control of Heartland is mainly connected to Russia/ USSR or a possible coalition of Russia and Germany. 
Rimland is a term coined by Nicholas J. Spykman (18931943), Sterling Professor of International Relations (19341943) at Yale University (Spykman 2007 [1942]; Spykman 1944). Rimland includes the coastal areas of Eurasia that surround the continental core of Heartland, i.e. Europe, the Middle East, the Arab Peninsula, the Indian Peninsula and Southeast Asia. Strategic control of Rimland according to Spykman is more essential than actual control of Heartland for world dominion. During the Cold War, Spykman's hermeneutic model was implemented on a strategic level, as the US attempted to preserve its strategic influence in parts of the coastal Rimland, as in Korea and in Vietnam.

The validity of Classical Geopolitics and its accompanying set of concepts and general hermeneutic framework, including such loci as Heartland, Rimland and the fundamental distinction between sea and land powers, has been a matter of discussion in the theory of International Relations. The use of loci of Classical Geopolitics has of course been criticised in the work of Critical Geopolitics (Tuathail 1992; Tuathail 1996) as representing an 'essentialist' perception of space and power distribution. Our use of Classical Geopolitics as a valid hermeneutic framework is connected to the macro-historical overview of our analysis and is based on the immutability of geographical data and the long-term persistence of the major strategic priorities of the states involved. The phenomenon of the Soviet Union/Russia controlling the Eurasian interior and its attempt to project power on the coastal periphery that in essence is Western Europe and the Eastern Mediterranean has steadily manifested from the 19th century up to the early 21st century, albeit in varying forms. Western sea powers, defined as such by their projection of power with the use of aeronautical forces and sea routes, continue to focus their attention on specific points of Rimland, as they have done in the past, in their attempt to avert control of the Eurasian landmass by a major land power or a combination of two major land powers. The perception of geography may change according to ideological inclinations of each period, including the current prevalence for post-modern deconstruction, but physical geography itself, i.e. the location of states, the relation of spatial realities to strategic goals of the states and the main axes of their power projection, does not change in essence in the long term.

\section{Greece as part of Rimland}

Greece was founded as an independent state in 1830, after a 7-year armed revolt against the Ottoman Empire that proved successful in the coastal areas of southern Greece and the islands of central Aegean Sea. Access of Western sea powers of the time, i.e. Great Britain and France, to the coastal areas facilitated the ability to project power against the Ottoman Empire, and this power was manifested in the naval Battle of Navarino (1827), which effectively guaranteed Greek self-rule. The very birth of Greece as an independent state actor is thus intricately connected to its geographical location and its maritime dimension. (Kotoulas 2020).

According to Mahan, maritime power as a term concerns purely military power, i.e. the military navy and installations; sea power carries a broader meaning, including not only military maritime power, but also the merchant fleet and trade and sea communication (Mahan 1890). In this sense, Greece carried considerable sea power with its geographical location, its sea expertise, its considerable wear fleet and its huge merchant fleet. Historically, Greece has always been strategically linked to Western hegemonic actors able or willing to project sea power in the Eastern Mediterranean, such as Great Britain in the late 19th and early 20th century and the US since 1947 (Kotoulas 2020).

Greece is a sea power due to its geophysical formation, its geographical location, its expertise and its geostrategic orientation. Greece features an extended coastline with many suitable ports. The Aegean Sea is the intermediate sea hub between the closed Black Sea, the Mediterranean and the semi-closed Adriatic Sea. Control of the Aegean Sea offers a state actor the capability to project power from the Otranto Straits to the west through the Corinth Canal towards the Dardanelles and the coastline of North Africa to the south. The Greek state comprised both maritime power and sea power.

\section{The Greece, Turkey, Iran (GTI) corridor as part of Rimland}

Greece and Turkey both belong to the geopolitical unity of Rimland; together with Iran, the three states formed in Western strategic thinking the so-called Northern Tier or GTI Corridor, which was also complemented by Pakistan to the east. The GTI Corridor was the keystone of Western security in the Eastern Mediterranean and Western Asia, as this extended territorial unity blocked power projection of the Soviet Union to the warm seas, i.e. the Mediterranean Sea and the Indian Ocean.

The strategic importance of this spatial unity was demonstrated already in the first stages of the Cold War, 
becoming the hotbed of the initial confrontation of the two blocs. In the late 1940s, the Soviet Union attempted to undermine the strategic cohesion of the GTI Corridor and project its strategic influence in all three countries of the GTI Corridor. In Greece there was an insurgency of pro-Soviet militias which was fully supported by countries of the Eastern Bloc both logistically and diplomatically, especially during the last phase of the communist insurgency (1946-1949). In Turkey, Soviet pressure manifested itself as an official request to obtain joint control of the Black Sea Straits and as a direct threat of invasion in 1946. In Iran, the Soviet Union undermined the Western orientation of the country by backing the ethnic revolts of the Kurdish and Azeri populations against the central Iranian government (Knight 1975; Roberts 2011).

The elevated strategic importance of the GTI Corridor was fully grasped by US officials at the time. Joseph Marion Jones (1908-1990), an official of the US Department of State and a member of an advisory committee of American President (1945-1953) Harry S. Truman (18841972) highlighted the strategic importance of Greece for US interests and its position in the GTI Corridor. According to Jones, the Soviet Union aspired to undermine this geostrategic spatial unity and exert influence in a wide area comprising the Eastern Mediterranean, the Middle East and the Indian Ocean, resorting to tactics that reminded the imperial policy of the Tsarist Russian Empire (Jones 1955, p. 11; Stephanson 2000, pp. 81-82).

The Truman Doctrine, declared on 12th March 1947 during the Greek Civil War, became the foundation of American foreign policy for the Cold War period. In relation to Greece, the Truman Doctrine was the ideological expression of American hegemonic presence in Greek matters. In this context, the US effectively substituted Great Britain as a regional hegemonic power in Greek matters (Anderson 1981, pp. 161-162). The Truman Doctrine essentially confirmed the commitment of the US government to provide diplomatic, financial and technical assistance to Greece and Turkey against the armed opposition of Communist militias, as was the case with Greece, or external threats of invasion, as was the case with Turkey (Wittner 1980; Kaplan 2013, p. 4). Truman himself stated that the two states represented 'free people who are resisting attempted subjugation by armed minorities or outside pressures' (Truman 1947; Pach 1991, pp. 88-90).

The strategic Truman Doctrine was supplemented by the ambitious financial Marshall Plan that assisted in the regeneration of war-torn Western Europe (Kaplan 2013, pp. 4-5). The Marshall Plan provided Greece with 1 billion US dollars from 1948 till 1952, facilitating reconstruction of the territory, after a 10-year turmoil that had begun with
WWII and continued with the Greek Civil War. The external financial aid provided was combined with increased political influence by the US in the unstable environment of Greek democracy, lasting until 1952 (Wittner 1983, pp. 167-191). The creation of a more stable political environment in Greece after 1952, when the conservative party initiated an 11-year political rule, coincided with the entry of the country into the NATO structure.

\section{Entry of Greece in NATO}

NATO as a military alliance was founded in 1949 during the early phase of the Cold War between the Western democracies and the Eastern totalitarian states. NATO was a security framework acting under Anglo-Saxon hegemony with the explicit strategic goal of maintaining balance of power in war-torn Europe and to stop Soviet expansionism that had already engulfed Eastern Europe. In effect, NATO aimed to erase the existing possibility of Western democracies becoming subject to the equivalent of a Soviet hegemony that would complete indirect control over the whole of the European continent. (X [Kennan] 1947; Gaddis 1982, p. 10).

In this context, NATO was an intercontinental military alliance of sea powers that was established as a defence mechanism in opposition to the purely continental bloc of land powers formed by the Soviet Union and its dependent East European states. The communist states of Eastern Europe comprised a protective belt safeguarding the Soviet heartland from any attack. Still, the advance of Soviet imperialism did not manage to engulf any seaoriented state. It is interesting that the only state where a violent civil war was Greece, a typical sea power due to its geophysical formation with extended coastline and its human capital. (Kotoulas 2020).

Concerning the early years of NATO, it may be said that the founding states of NATO were not enthusiastic concerning the candidacies of Greece and Turkey. The two states were considered to lie outside the main geographical area of interest for NATO members. (Haas and Mcdonald 1988). Up until 1950, NATO was perceived by its members as a security framework dedicated to defence of the Western European core. Objection to Greek and Turkish membership could also stem from cultural concerns, as the two states did not belong to the Protestant-Catholic core of Western Europe and European-born North American societies that coincided with the founding NATO members. Greece is an Orthodox country, and still is; its historical identity and self-perception are mainly connected to the widely prevalent perception of ancient Greece as a 
founding state of the Western world. Finally, a history of intense confrontations between Greece and Turkey that had unfolded in the early 20th century could also prove to be a point of concern. As it turned out, historical GreekTurkish rivalry did not disappear and re-emerged already in the 1950s, but after both countries had become NATO members.

The decisive event that transformed American perception of Greece's strategic importance for Western interests was the Korean War (1950-1953). It was at that time that the Western states realised the inherent expansionist policies of the Communist power bloc and of Soviet revisionism of the existing status quo (Kaplan 1983, pp. 145-146). The conflict in Korea was not treated as an isolated regional incident but was rightly perceived as an explicit expression of Soviet and generally Communist revisionism along the whole expanse of Rimland, from Eastern Asia to Western Europe. The Communist-controlled Heartland had been considerably expanded with the inclusion of China after the victory of the Communist under Mao Tse-Tung in 1949.

In this context of confrontation between the Western world and the emerging Eurasian power bloc, Greece's strategic importance increased for American considerations, foreboding Greece's entry into the NATO structure. In a memorandum issued by the US National Security Council in February 1951 titled The Position of the United States with Respect to Greece, the strategic importance of Greece for US and Western interests was analysed in detail:

\footnotetext{
1. It continues to be in the security interest of the United States that Greece not fall under communist domination. a. Greece occupies an important strategic position which, in the hands of an enemy, would be a threat to the Eastern Mediterranean, the Suez, Turkey and the Turkish Straits. Communist domination of Greece would serve as a springboard for communist penetration, political and military, into the Eastern Mediterranean and Near East area. b. Communist domination of Greece would damage U.S. prestige and weaken the will to resist in other countries threatened with communist domination. c. Communist domination of Greece could only be viewed as one in a series of military and political consequences which would gravely threaten the security of the United States. (Foreign Relations of the US 1951 Vol. V, 1982).
}

In May 1951, the US Department of State officially decided to raise the issue of joint membership for Greece and Turkey in NATO. The inclusion of the two states would expand the geographical territory of NATO jurisdiction to the Eastern Mediterranean and Western Asia. Greece and Turkey, viewed in NATO strategic thinking, as a unity, would create the south-eastern flank of the Western defence system (Smith 2000). This essential power bloc would avert Soviet expansionism by effectively blocking the Dardanelles Straits. Turkey controls the upper exit of the Bosporus Straits, while Greece controls the exit to the Mediterranean Sea. In September 1951, the North Atlantic Council formally extended an invitation to both Greece and Turkey to become members of the North Atlantic Pact. The two states were admitted in February 1952.

\section{An overview of Greece's NATO membership}

The entry of Greece into NATO in 1952 was a decision of unprecedented historical importance. Greece became a member in the most powerful military alliance of modern history. Regarding the historic background of the era, Greece's aspiration to enter the NATO alliance was intricately linked to its precarious geostrategic position on the frontline of the Western world. Greece was the only Western country and only NATO member to share land borders with three socialist states, i.e. Albania, Yugoslavia and Bulgaria, all of which had also in the recent past expressed aggressive stance against Greek sovereignty. Concerning the benefits of NATO membership for Greece itself, the fundamental NATO doctrine during the early phase of the Cold War (1949-1962) was grounded on the concept of massive retaliation. In effect the doctrine meant that any attack on Greek borders by a country of the Eastern Bloc would be considered a casus belli for the NATO alliance (Wells Jr., 1981). Until 1955 when the Greek-Turkish rivalry reached its first peak, Bulgaria was considered the main external threat for Greek interests (Chourchoulis 2012). The geographical formation of the borders with Bulgaria and Yugoslavia offered no advantage to Greece as the latter lacked strategic depth to develop its defending forces or even plan a counterattack.

Initially, Greek membership in NATO structure was aptly combined with a proactive foreign policy and commitment to the strategic interests of the US as the de facto hegemonic actor in NATO. Greece contributed armed forces to the Korean War (GES/DIS 1977), and approved the installation of US bases in Greece (1953) and the hosting of American nuclear missiles (1960). On a tactical level, Greece attempted to use its strategic frontline position. In this context, Greece was sceptical vis-à-vis the prospect of détente; Greek officials were worried that an eventual US-Soviet rapprochement would reduce Greece's strategic value as a frontline state in the context of the Alliance. Greece aimed to use its NATO membership to extract 
diplomatic gains on the Cyprus Issue, which had come to the forefront in the early 1950s.

Considering Greek-Turkish relations, the joint inclusion of the two countries in the NATO structure was meant to form a combined strategic bloc controlling access to the Black Sea and the Eastern Mediterranean. This view disregarded the longue duree of history in the region. In 1955, as a result of different national approaches to the Cyprus Issue, the drastic deterioration of Greek-Turkish relations began.. Cyprus, a former part of the Ottoman Empire under British dominion since 1878 and a British Crown colony since 1925, had a Greek population majority of $80 \%$ as opposed to a Turkish minority of $18 \%$. Greek Cypriots initiated a liberation fight against British dominion in 1955 ending in 1959 when Cyprus became independent. Greek strategic priorities shifted from the Balkan hinterland to the Eastern Mediterranean. Greek-Turkish inter-state tension intensified even after the declaration of Cyprus independence in 1959, as violent inter-communal clashes occurred in 1963-1964 between the Greek and the Turkish ethnic populations of Cyprus. Greece was evidently disappointed in NATO's neutrality in the dispute with Turkey and its apathy considering the Turkish pogrom of 1955 against the Greeks of Constantinople (Holland 1995; Chourchoulis and Kourkouvelas 2012).

Greece's strategic value for Western interests was increased after 1967 due to the Six-Day Arab-Israeli War (5-10 June 1967) and the increased presence of the Soviet fleet in the Mediterranean during the early 1970s. The new orientation of Greece towards the Eastern Mediterranean now extended not only to Cyprus, but also to Israel. Characteristically, in August 1972, the American President (19691974) Richard Nixon (1913-1994) stated that there could not be an effective policy of aid to Israel without strategic help towards the adjacent countries of Greece and Turkey.

The Turkish invasion of Cyprus in July and August 1974 initiated a series of grave strategic errors by the Greek side. Under the conservative government (1974-1980) of Konstantinos Karamanlis (1907-1998) and the influence of the French model, Greece withdrew its forces from NATO's military command structure in August 1974. The Greek side had expected the intervention of NATO to negate the results of the Turkish invasion; inactivity of NATO for the strategic security of Cyprus, a non-NATO member, had undermined Greece's confidence in the Alliance (Manousakis 1981). With its withdrawal from NATO's military command, Greece attempted to assert the strategic importance of the country for the cohesion of the NATO alliance in the South-Eastern Mediterranean. Greek withdrawal from NATO structure would cause the following problems: the Sixth Fleet would face logistical problems, Turkey as the eastern-most member would be isolated from Italy over 700 miles, the Soviet Fleet would move into the Eastern Mediterranean to fill the strategic gap and the US would have problems in supporting Israel and pro-Western North African states. Still, damage to Greek interests was even greater, as its relative value in the Alliance was reduced and its frontline position eradicated (Collins 1975).

Greek withdrawal was a serious tactical error, as Greek officials had made two fundamental miscalculations. The first one was that they overestimated the damage that would be inflicted on the strategic cohesion of the south-eastern Flank of NATO from Greece's absence. The second one was that they expected the US to exert considerable diplomatic pressure over Turkey, with the aim of withdrawing its occupying forces from the northern part of Cyprus (Rizas 2009).

From 1974 till 1980, Greece retained its links with NATO, gradually attempting to return to the military command. Greece also oriented itself towards the expanding European Community, achieving European Community membership in 1981 (Rizas, 2008). Greece viewed the European Community as a possible strategic substitute for NATO under French leadership, an assumption that never materialised (Manousakis 1981).

Greek military forces were readmitted in NATO command structure in October 1980, during a period of great power redistribution in Rimland and especially in its crucial component in Western Asia, the Northern Tier. The 1979 Islamist revolution in Iran amounted to the elimination of Iran from the GTI Corridor that blocked Soviet access to Rimland. The parallel Soviet invasion in Afghanistan in December 1979 increased the strategic importance of the two other remaining states of the Northern Tier, i.e. Turkey and Greece. The elevated strategic priority of Turkey for US interests originates in this period when the US sought to guarantee its interests in the volatile Middle East. At the same time, Greece failed to take advantage of the new strategic environment, as Greek officials adopted an ambiguous stance towards the country's traditional pro-Western orientation. Characteristically, in 1978 and again in 1979, Greek authorities refused to consent to the installation of additional US military bases or US personnel that would be relocated from Iran to Greece. As Greece attempted to reorient itself towards Europe, Turkey instead transformed itself in the 1980s into an indispensable ally for US and NATO interests due to the crisis in Iran and Afghanistan.

Since 1974, when it had initially abandoned the military branch of NATO, Greece had been entangled in a new self-perception concerning its geopolitical position and strategic priorities. This new mentality was plagued 
with and was aptly expressed during the 1980s under the socialist government (1981-1989) of Andreas Papandreou (1919-1996). Papandreou was opposed to the maritime dimension of Greek geopolitical self-perception and its strategic connection to Western sea powers, instead emphasising the intermediate position of Greece between the two blocs and making overtures towards the NonAligned Movement. During this whole period (1974-1989) and especially during the 1980s, Greece was perceived in Western security circles as an untrustworthy ally for the US and even a potentially destabilising factor for the coherence of NATO (Coufoudakis and Valinakis 1987, pp. 30-35; Couloumbis 1993).

The dissolution of the Soviet Union in 1991, the outbreak of the Yugoslav Civil War (1991-1995) and the subsequent turmoil in the Balkans, Greece's northern hinterland, provided Greece with a large strategic advantage in the long run despite initial security concerns. Greece became overnight the strongest and evidently most advanced state in the Balkan region using its NATO and EU membership as a comparative advantage. The break-up of Yugoslavia further removed a powerful state actor from Greece's northern borders, which continued to pose security challenges to Greece especially with its claims for the existence of a so-called Macedonian minority in Greece. In the early Cold War period, Yugoslavia had actively participated in hostile actions against the territorial integrity of Greece in 1946-1948 by supporting Communist separatist insurgents in northern Greece.

The Macedonian Question re-emerged in the 1990s with the dissolution of Yugoslavia and the independence of FYROM (North Macedonia since 2019). Former Yugoslav Republic of Macedonia (FYROM) declared itself the Republic of Macedonia in 1991 and used an expansionist agenda against Greece, which included cultural appropriation of Greek history. Greece blocked international recognition of FYROM under its new name and inter-state tension peaked in the 1994 trade embargo imposed by Greece. Bilateral relations were normalised in 1995; still, Greece continued to avert the entry of FYROM into NATO or the EU until 2019. The Prespes Agreement (2019) and recognition of this state by Greece led to the signing and subsequent ratification of the Accession Protocol by representatives of NATO member states. North Macedonia thus became a member state of NATO in March 2020. Greece's frontline mentality in the Balkan hinterland thus reached its end, as the region was categorised as a safe environment with its inclusion in NATO structure and partially in EU structure.

After the Imia incident in 1996, when the war fleets of Greece and Turkey came nearly to engage in hostilities in the Aegean Sea, Greece reduced its dependency on the US regarding its interference as unproductive vis-à-vis Greek national interests. Greece distanced itself from the Western sea powers and reoriented itself towards the continental EU bloc that had recently been transformed into a proto-political union. For a period of nearly 15 years, up until the early 2010s, Greece attempted to become part of an EU security structure revolving around the FrancoGerman diplomatic axis. This diplomatic choice undermined Greece's strategic value abolishing its frontier dimension in both the Balkans and the Mediterranean and hindered its orientation towards the vital Mediterranean Sea. Greece's priorities at that time consisted of developing an economic hinterland in the Balkans and entering the economic hard core of EU by becoming a member of the Eurozone.

\section{Greece as a frontline state in the early 21st century}

Greek geopolitical self-perception begun to drastically change in the early 21st century and this change is attributable to a combination of both internal and external factors. The serious fiscal crisis of Greece that unfolded since 2009 and lasted approximately until 2019 imposed the necessity of a new strategic thinking. This new strategic self-perception would be based on the country's intermediate geographical position in the Eastern Mediterranean and the need to reaffirm its membership in the Western hard core of power politics. Greece had by then realised the strategic inadequacy of the existing EU structures and its ability to address Greek security concerns, as the Mediterranean became increasingly volatile. The advent of an increasingly revisionist Turkey was the main external factor that caused Greece's repositioning in the new unstable geopolitical environment of the Eastern Mediterranean. Since 2010, Greece actively projected power in the Eastern Mediterranean, which became the new advanced frontier zone of Greek national interests. In this context, Greece reinvented itself as a frontline state, this time oriented in the Mediterranean Sea. The maritime dimension of Greece's geopolitical identity resurfaced, and a new power balance has been forming in the Eastern Mediterranean.

Turkish foreign policy and interventions in Syria and in Libya and in the Eastern Mediterranean has led to a counter-balance coalition between overlapping networks of state actors including Greece. Greece, Cyprus and Egypt; the three states ratified a joint tripartite treaty in 2014. Greece, Cyprus and Israel began collaborating 
on a diplomatic, economic and military level. In 2020, Greece and Egypt signed a deal for the partial delimitation of their Exclusive Economic Zones and decided to further enhance their military ties. On an economic level, the East Mediterranean Gas Forum was founded in 2019 by a network of closely working states including Greece, Cyprus, Egypt, Jordan and Israel. Greece's new selfperception as a frontline state has manifested itself in the deepening of ties with the US and enhanced military cooperation.

\section{The New Rimland}

The major underlying development for the Greek new frontier mentality is the re-emergence of the strategic importance of Rimland for Western states and their allies. Rimland as a geopolitical spatial unity has been altered due to the unification of the Eurasian landmass because of China's economic rise and the rapprochement between major actors of Eurasia, all of which are land powers on a geopolitical level: Russia, China, Iran and lately Turkey. As noted above, during the Cold War, Rimland was used to avert power projection by USSR, the state actor controlling Heartland, on Eurasian periphery. A vital part of Rimland was the Northern Tier or GTI Corridor consisting of Greece, Turkey and Iran. This strategic corridor was undermined first in 1979 with the Islamist Revolution in Iran and in the last years by the interference of Russia in various countries, most notably Syria and Libya.

In this context, the hermeneutic spatial model of Rimland needs a new definition.

The New Rimland, defined thus to distinguish it from the typical spatial unity of Classical Geopolitics, comprises a network of geopolitical territorial entities that extend around the continental core of Eurasian states controlling Heartland:

i) the Three Seas Initiative, a joint project of twelve member states in Central and Eastern Europe. The Three Seas Initiative forms a strategic economic axis from the Baltic Sea to the Black Sea with the aim of securing energy security for Europe and independence from Russian influence (Górka 2018);

ii) the Mediterranean and Indo-Arabic core, an evolving, spatially fragmented geopolitical unity including Greece, Cyprus, Israel, Egypt, Saudi Arabia, United Arab Emirates, Bahrain and at its eastern-most extension India; (Kotoulas 2021); iii) the Indo-Pacific core including the pro-Western coastal states of Australia, New Zealand, Thailand, Philippines, Taiwan, South Korea and Japan.

As a member of the Mediterranean core of the New Rimland, Greece's position is essential in this power structure with two main axes. Greece already acts as a forward base for the deployment of NATO troops in Eastern Europe through its ports located in its northern territory, in Salonica and Alexandroupolis, which provide access to the Black Sea and outflank Turkish control of the Bosporus Straits. The second direction of power projection is towards the Eastern Mediterranean and is connected to control of the Aegean Sea. The aeronautical Souda base in Crete is the most effective US base in Europe and the Mediterranean in terms of potential output. It is thus essential to recognise the strategic importance of Crete, an island strategically situated close to the European mainland and in vicinity with North Africa. Crete could be upgraded to become the fundamental hub for US and NATO power projection in multiple directions, towards the Black Sea, the Eastern Mediterranean, the Middle East, North Africa and the Sahel region. Greece has formed a diplomatic alliance with France, a state that attempts to reassert its influence in the Mediterranean and North Africa. In this context, France functions on a geopolitical level as a sea power in relation to Greece and the strategic environment of the Eastern Mediterranean. France's active diplomacy is supplemental to the interests of the Western sea powers, mainly the US.

\section{Conclusions}

On a macro-historical level, Greece has experienced two different phases in its self-perception as a frontline state. The first one unfolded since 1952-when Greece became a NATO member-until 1974 and Greek withdrawal from the military branch of the Alliance. During this period that coincided with the climax of the Cold War, Greece was a frontline state of the Western security nexus in relation to the Balkan hinterland, and then dominated by socialist States. After the end of the Cold War and an intermediate period of orientation towards the continental EU diplomatic bloc, Greece reinvented itself as a frontline state, this time in the Eastern Mediterranean.

This strategic realigning is related with Greece's historical ties to Cyprus, a state populated by a majority of ethnic Greeks, and the traditional maritime dimension of Greece. To further its strategic goals in the Mediterranean Greece needs the constant support of the main sea 
power, the US. The creation of a new diplomatic network in the Eastern Mediterranean comprising Greece and other states is unfolded in the spatial geopolitical entity we define as the New Rimland. The New Rimland unites pro-Western states that oppose the emerging power nexus of Eurasian land powers. Greece tends to perceive its strategic position as that of a frontier state of the Western Atlantic core in relation to the Black Sea and the Eastern Mediterranean Sea, thus confirming its spatial maritime strategic orientation that has been a constant feature of its geopolitical character since its foundation in the early 19th century.

\section{References}

Anderson, T. H. (1981). The United States, Great Britain, and the Cold War 1944-1947. University of Missouri Press, Columbia and London.

Braudel, F. (1958). Histoire et sciences sociales: La longue durée. Annales 13-14, 725-753.

Chourchoulis, D. (2012). A nominal defence? NATO threat perception and responses in the Balkan area, 1951-1967. Cold War History, 12(4), pp. 637-657.

Chourchoulis, D., \& Kourkouvelas, L. (2012). Greek Perceptions of NATO during the Cold War. Southeast European and Black Sea Studies, 12(4), pp. 497-514.

Collins, J. M. (1975). Greece and Turkey: Some Military Implications Related to NATO and the Middle East: Prepared for the Special Subcommittee on Investigations of the Committee on Foreign Affairs. US Government Printing Office, Washington DC.

Coufoudaki, V., \& Valinakis, Y. G. (1987). The evolution of Greece's defense strategy in relation to NATO contingencies. The International Spectator, 22(1), pp. 30-35.

Couloumbis, Th. A. (1993). PASOK's foreign policies, 1981-89: Continuity or change? In: Clogg, R. (ed.), Greece, 1981-89: The Populist Decade. Palgrave Macmillan, London, pp. 113-130.

Foreign Relations of the United States 1951, The Near East and Africa, Vol. V, Document 212, NSC 103/1. (1982). United States Government Printing Office, Washington DC Available at https://goo.gl/vhsgdH.

Gaddis, J. L. (1982) Strategies of Containment. Oxford University Press, New York.

GES/DIS (ed.) (1977). To Ekstrateftikon Soma Ellados eis Korean 1950-1955 [=The Greek Expeditionary Force in Korea, 1950-1955]. Athens.

Górka, M. (2018). The three seas initiative as a political challenge for the countries of Central and Eastern Europe. Politics in Central Europe, 14(3)), pp. 55-73.

Haass, R., \& Mcdonald, R. (1988). Alliance Problems in the Eastern Mediterranean-Greece, Turkey and Cyprus: Part I. In: O'Neill, R. (ed.), Prospects for Security in the Mediterranean. Palgrave Macmillan, London, pp. 61-89.

Holland, R. (1995). NATO and the struggle for Cyprus. Journal of Modern Greek Studies, 13(1), pp. 33-61.

Jones, J. M. (1955). The Fifteen Weeks: February 21-June 5, 1947. Viking Press, New York.
Kaplan, L. S. (1983). The United States and NATO: The Formative Years. The University Press of Kentucky, Lexington, KY.

Kaplan, L. S. (2013). NATO before the Korean War: April 1949-June 1950. Kent State University Press, Kent, $\mathrm{OH}$.

Knight, J. (1975). American Statecraft and the 1946 Black Sea Straits Controversy. Political Science Quarterly, 90(3), pp. 451-475.

Kotoulas, I. E. (2020). Greek strategy in the aegean sea during the Ottoman period and World War I'. In: Çomak, H., Şeker, B. Ş., \& Ioannidis, D. (eds.), Ege Jeopolitiği, Vol. I. Nobel, Ankara, pp. 765-771.

Kotoulas, I. E. (2021). India and Greece as strategic partners. Defence and Security Alert, 12(7), pp. 34-39.

Mackinder, H. J. (1904). The geographical pivot of history. Geographical Journal, 23, pp. 421-437.

Mackinder, H. J. (1919). Democratic Ideals and Reality: A Study in the Politics of Reconstruction. Holt, New York.

Mahan, A. T. (1890). The Influence of Sea Power upon History. Little, Brown \& Co., Boston.

Manousakis, G. M. (1981). Der Aus- und Wiedereintritt Griechenlands in die militärische Integration der NATO. Beiträge zur Konfliktforschung, 2, pp. 19-32.

Pach, C. J. Jr. (1991). Arming the Free World: The Origins of the United States Military Assistance Program, 1945-1950. The University of North Carolina Press, Chapel Hill and London.

Rizas, S. (2008). Atlantism and Europeanism in Greek foreign and security policy in the 1970s'. Southeast European and Black Sea Studies, 8(1), pp. 51-66.

Rizas, S. (2009). Managing a Conflict between Allies: United States Policy towards Greece and Turkey in relation to the Aegean Dispute, 1974-76. Cold War History, 9(3), pp. 367-387.

Roberts, G. (2011). Moscow's Cold War on the Periphery: Soviet Policy in Greece, Iran, and Turkey, 1943-8. Journal of Contemporary History, 46(1), pp. 58-81.

Smith, M. (2000). NATO Enlargement during the Cold War: Strategy and System in the Western Alliance. Palgrave, New York.

Spykman, N. J. (1944). Geography of the Peace. Wartime Books-Harcourt, New York.

Spykman, N. J. (2007[1942]). America's Strategy in World Politics: The United States and the Balance of Power, with a New Introduction by Francis P. Sempa. Transaction, Piscataway, NJ.

Stephanson, A. (2000). 'Liberty or Death': The Cold War as US Ideology. In: Westad, O.E. (ed.), Reviewing the Cold War: Approaches, Interpretations, Theory. Routledge, London and New York, pp. 81-100.

Truman, H. (1947). Address to Joint Session of Congress, 12 March 1947, Truman Library, Independence, MO, Available at avalon. law.yale.edu/20th_century/trudoc.asp.

Tuathail, G. Ó. (1992). Putting Mackinder in his place: Material transformation and myth. Political Geography, 11, pp. 100-118.

Tuathail, G. Ó. (1996). Critical Geopolitics. Routledge, London and New York.

Wells, S. F. Jr. (1981, Spring). The origins of massive retaliation. Political Science Quarterly, 96(1), pp. 31-52.

Wittner, L. S. (1980, Spring). The Truman doctrine and the defense of freedom. Diplomatic History, 4(2), pp. 161-187.

Wittner, L. S. (1983). American Intervention in Greece, 1943-1949. Columbia University Press, New York.

X [George F. Kennan]. (1947). The sources of Soviet conduct. Foreign Affairs, 25(4), pp. 575-576. 